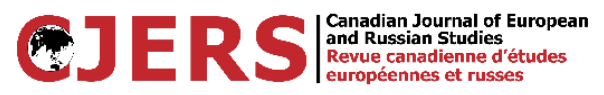

\title{
Environmental Issues in Recent British and Canadian Elections
}

\author{
Harold D. Clarke ${ }^{1}$, University of Texas at Dallas \\ Jon H. Pammett ${ }^{2}$, Carleton University
}

\begin{abstract}
The 2019 elections in Britain and Canada illustrate the difficulties in communication between a concerned public and prospective office-holders on the most critical set of issues of our times. An increased level of public awareness and concern about the state of the environment has been expressed in public opinion polls, social movement activity has increased, and Green parties have expanded their appeal. Despite these developments in recent years, environmental issues have not been able to exert a major impact on individual voting behaviour in elections, or on overall election outcomes. Issues related to the environment are usually treated, by both politicians and the public, in valence terms. Valence issues are ones upon which there is broad consensus about the goals of public policy, and political debate focuses not on "what to accomplish" but rather on "how to do it" and "who is best able". Regarding the environment, general formulations like global warming and climate change prompt politicians to offer concerned rhetoric and engage in virtue signaling, but specific policy proposals are often absent. This paper examines four reasons why environmental/climate change issues did not have a major impact on the 2019 Canadian and British elections. First, environmental concern in society at large was imperfectly translated into election issues. Second, the major political parties produced inadequate and unconvincing environmental manifestos. Third, environmental issues were not central to most voting decisions. Fourth, environmental issues had limited impacts on election outcomes.
\end{abstract}

\footnotetext{
${ }^{1}$ Harold D. Clarke is Ashbel Smith Professor in the School of Economic, Political and Policy Sciences at the University of Texas at Dallas.

${ }^{2}$ Jon H. Pammett is Distinguished Research Professor of Political Science at Carleton University, Ottawa, Canada.
} 


\section{Introduction}

Whether defined as global warming, climate change, or simply the environment, issues related to the state of the physical world have captured the public's attention and generated widespread concern. To date, however, the effects of these issues on voting behaviour and election outcomes have been modest. This article will focus on the 2019 national elections in the United Kingdom (UK) and Canada, countries with comparable parliamentary systems of government. The contexts of these elections illustrate two situations where environmental issues faced different kinds of problems. In Britain, environmental concern was swamped by protracted and bitter controversy over whether the country should leave the European Union (EU) and, if so, under what conditions. In Canada, environmental concerns were joined by other large problems (the health system, the economy) at the top of the issue agenda. We focus on the role which democratic theory gives to elections as the main mechanism for systematic public instruction to governments about the desirable direction of public policy (Clarke, Jenson, LeDuc and Pammett 2019). Of course, elections are only one avenue for influence on policy, but they are the one which involves the population at large. As we shall see, the governments produced by the 2019 elections in the two countries were granted "policy mandates' on the environment that were no clearer than those accorded to their predecessors.

Worldwide, concern over climate change varies in its urgency. In the Pew Research Center's 2018 survey of global threats, climate change was at the top in half of the 26 countries surveyed, with people in other countries being more concerned about terrorist threats and cyberattacks (Poushter and Huang 2019, 3). However, in the IPSOS monthly poll of "what worries the world", the September 2019 results show that climate change was only number eight on the list, following unemployment, crime and violence, financial and political corruption, poverty and social inequality, healthcare, education, and taxes (IPSOS 2019). After the coronavirus pandemic captured the world's attention in early 2020, COVID-19 surged to the top of such lists, further depressing identification of the danger posed by climate change. That said, recognition of more imminent threats to health or the economy does not necessarily diminish underlying environmental concerns (Meyer and Smith 2017).

The 2019 British and Canadian national elections were both held in conditions of increased public concern about the environment, and in particular "climate change". Figures 1 and 2 illustrate the emergence of the environment as a salient issue. In Britain, where the survey question allowed respondents to identify three important issues, data from 2010 to 2019 show that public concern started to rise in 2017, and by 2019 the environment trailed only Brexit and the health service as national problems (Figure 1). It is reasonable to conclude that, absent Brexit, the trio of healthcare, the economy and the environment would have dominated the British issue agenda.

In Canada, environment/climate change emerged as the top single national issue in 2019, followed by the economy and health (Figure 2). As in Britain, this situation contrasts with much of the recent past, when fewer than $10 \%$ of respondents to national surveys identified the environment as the most important problem facing the country. However, an Abacus Data poll in late March of 2019 suggested that climate change might be more significant than usual in the forthcoming federal election. Results showed that $12 \%$ said it would be "my top issue" (Anderson and Coletto, March 27, 2019). In retrospect this was an underestimate, since 26\% of 
those participating in the 2019 Canadian Election Study $(\mathrm{CES})^{3}$ spontaneously mentioned the environment as their top concern.

Identification as an important national problem notwithstanding, the environment failed to have a major impact on the most recent Canadian and British elections for several reasons. One of these, which we will not discuss at length here, is undoubtedly related to the nature of the electoral system in both countries. As political scientists long have recognized, a single-member plurality electoral system makes it difficult for small parties to elect Members of Parliament (e.g., Duverger, 1954). The British and Canadian Green parties, with action to alleviate climate change at the top of their agendas, are typical examples. In several elections stretching back to the 1980s in both countries, these two parties never elected more than one Member of Parliament. The situation remained largely unchanged in 2019 with three Green MPs being elected in Canada and one in Britain (Everts and Harada, 2020: Carter and Pearson, 2020). However, in other electoral contexts, the Greens have done much better. For example, in the European Parliament elections of May 2019, conducted under proportional representation in the member states, the Greens elected their highest total of MEPs ever, with the environment the most important issue in that election (Pearson and Rudig, 2020). Similarly, in Germany, the Greens captured 67 of 709 seats in the Bundestag (lower house) in 2017 and were represented in 11 of 16 Länder (state)-level governments.

Figure 1: Brexit/Europe, Economy, Environment and Health Care as Important Issues, Great Britain, June 2010-December 2019

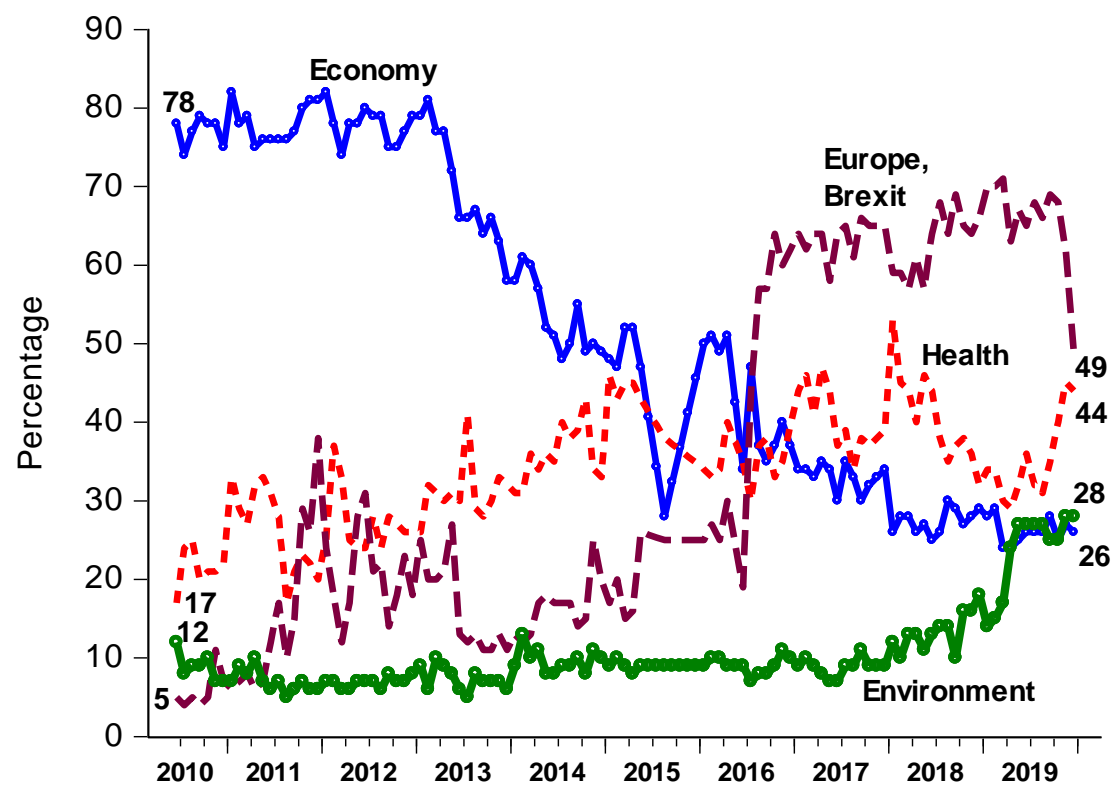

Source: YouGov and UTD-Essex surveys.

\footnotetext{
3 The 2019 CES data and supporting documentation are available at www.ces-eec.ca
} 
Figure 2: Economy, Environment and Health Care as Important Issues, Canada, April 2004October 2019

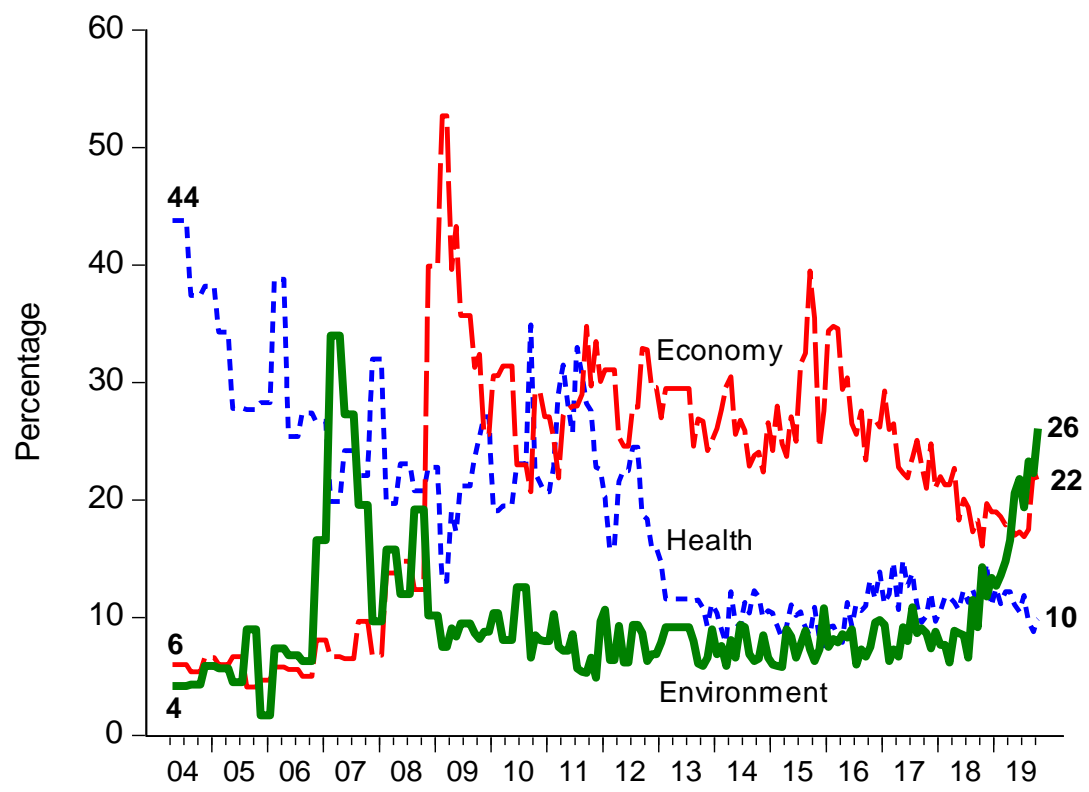

Source: Nanos Research; www.nanos.co

\section{Imperfect Translation into Election Issues}

When considering the salience of environmental issues, we will first examine how often respondents to election surveys mention these issues as most important for their voting decisions. The significance of environmental issues can vary according to how they are defined, as they are susceptible to various formulations. Key to the importance of this, or any other, issue type is the link to a party or party platform - are they differentially associated with various parties? Knowing this, we can move later to examining the patterns of voting choice based on the issues with a view to observing whether the voting patterns are skewed to benefit any party.

CES survey data show that mentions of the environment (also using general terms like global warming or climate change) as the most important election issue are generally quite sparse. Until the turn of the $21^{\text {st }}$ century, less than one percent of answers to open-ended election survey questions about respondents' most important election issues referenced the environment. Since then, there have been more mentions, but the norm prior to 2019 was around two or three percent. As Figure 3 shows, the exception was 2008 when close to nine percent of the survey respondents did so, likely in response to the widely publicized proposal of Liberal Leader, Stephane Dion, to implement a "Green Shift" in taxation through a carbon tax plan and various offsets. 
Figure 3: Most Important Issues in the 2004-2019 Canadian Federal Elections

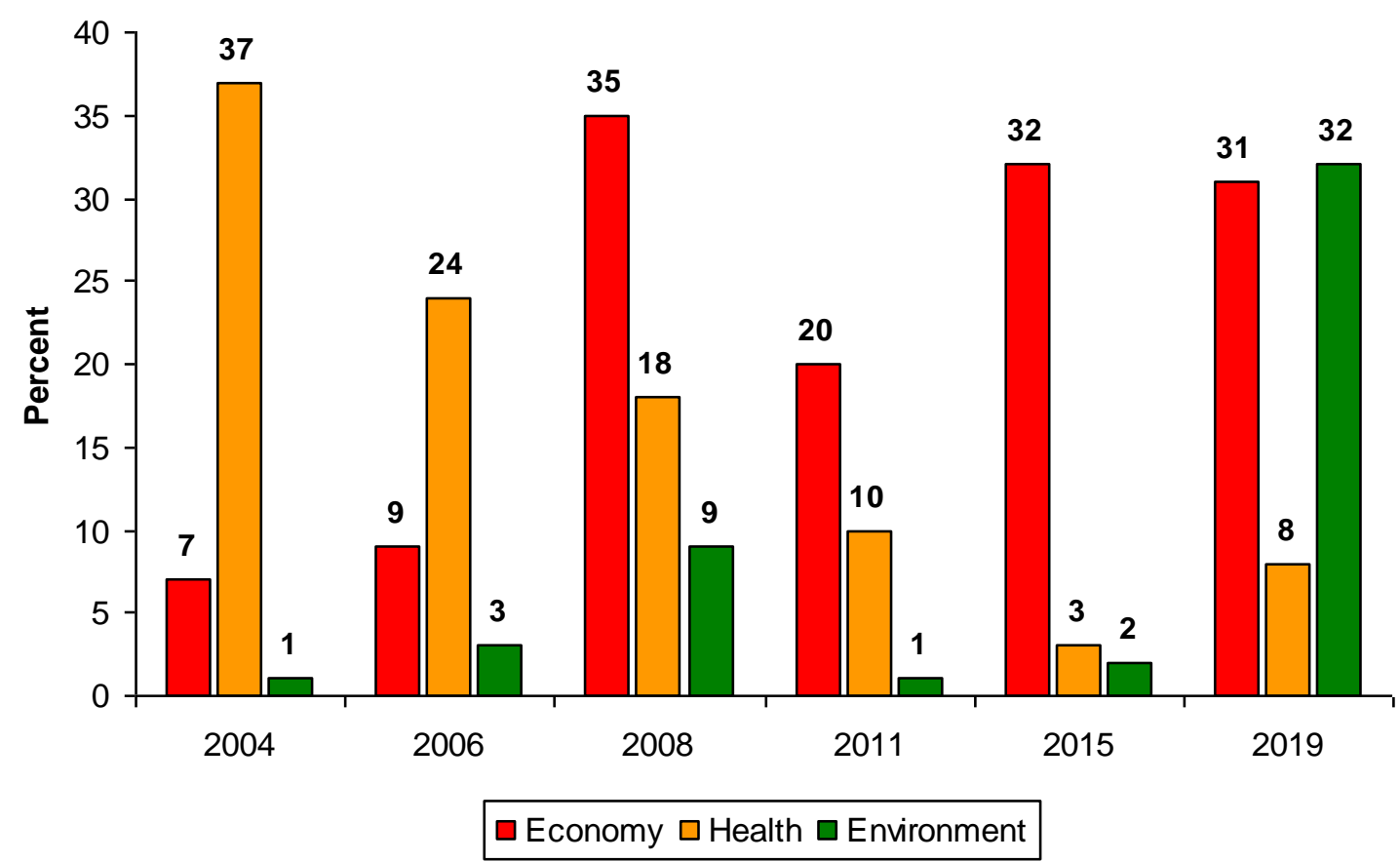

Source: 2004-2019 Canadian Election Study surveys.

In general, references to "the environment" as an important election issue are an example of public concern with a classic valence issue. These are major problem-type issues, which all parties agree are threats to national or personal well-being and promise to address in various ways (see, e.g. Clarke, Kornberg and Scotto 2009). Classic examples of valence issues are slowdowns to economic growth and rising unemployment and deficiencies in healthcare and other social welfare measures. With valence issues, all parties claim to be on the same side, public opinion is strongly skewed in that direction, and the parties compete to convince the electorate that they should be trusted to deal with the situation. Parties which have the advantage in public trust on a particular valence issue strive to raise its salience, while their rivals try to promote other issues, ones that they think will favour them. In the Canadian context, raising the salience of the environment usually has been difficult. This is partially because the Green Party, which has established a link to the issue in the public mind, has experienced difficulty competing due to the single-member plurality electoral system. Overall, environmental issues have had relatively minor effects on voting in Canadian elections or the results of these contests.

The environment can be blended with other issues in elections, including several that usually operate as valence issues. Four prominent ones are economic growth, employment, taxation, and energy. Links with these issues might work to the advantage of the environment; for example, implementing environmental protection policies might create new jobs and stimulate the development of new sources of energy production. Often, however, these other issues have dynamics of their own, which do not involve the environment. More detrimentally, in elections environmental issues are susceptible to framing on other dimensions in ways that work to their disadvantage. Examples are debates regarding the cost-effectiveness of government subsidies to 
environmentally-friendly industries or efforts to encourage consumers, such as the construction and installation of solar panels or the purchase of electric cars. The dispute over the benefits or drawbacks of nuclear power for the environment has a separate discourse.

In the Canadian context, the most important way in which discussions of environmental policy have been diverted has involved the subject of carbon taxation. There have been two prior Canadian federal elections where the subject of carbon taxation has been an important issue. The first instance, little remembered today, was in 1980. The 1980 election came as a result of the defeat of the Progressive Conservative (PC) minority government, led by Joe Clark, which came to power only in May of the previous year. The Clark government was defeated in Parliament over its budget in which Finance Minister John Crosbie proposed a tax of 18 cents a gallon (four cents a litre) on gasoline at the pump. It is not entirely clear why the Conservatives did this, since the proposal was never mentioned in the previous campaign, although it was justified in terms of both revenue and conservation. The budget bill was voted down in Parliament and the PCs were defeated in the ensuing election (Leduc and Pammett 2016).

Did the proposed tax influence the election result? In an analysis of voting patterns between 1979 and 1980, there is a slight overall PC advantage over the Liberals among those citing the budget, gasoline prices and the 18 cent tax as most important issues in the election. True, this came mainly from 1979 Conservative voters staying with their party in 1980, but switching patterns only slightly favoured the Liberals. The main negative factor for the PCs was not the budget or the tax but, rather, a very negative public judgment on Clark, which was arrived at for many reasons. What was clear was that protection of the environment got lost in the discussion of the tax and the ineptitude of the government (Clarke, Jenson, LeDuc and Pammett 1984, 167171).

The 2008 Canadian federal election was also called "early", in this case when Stephen Harper's minority government, in power since 2006, judged the circumstances were right to try for a majority. One of the reasons for this was the announced policy of the Liberal Party, then led by Stephane Dion. Dion had been a surprise victor in the Liberal leadership convention held two years before. Although he had been Environment Minister in the previous Liberal Government of Paul Martin, Dion had opposed the carbon tax plan advanced by another candidate, Michael Ignatieff, during the leadership campaign. However, Dion was converted to the idea, and proposed an elaborate "Green Shift" taxation plan during the election campaign. Through a combination of tax decreases and proposed rebates to low-income people, the proposed tax was defined as revenue neutral, so the campaign position was that it was a tax shift not a tax increase. However, the Harper Conservatives saw their opportunity to attack the Liberal proposal as a "tax on everything", given the ubiquitous nature of carbon. They promoted their leader's economic competence and offered a "cap and trade" alternative for environmental policy. The Conservatives won re-election, but not a majority (Pammett and Dornan 2008).

Once again, we can ask, how strategically disastrous was the Green Shift proposal in 2008? Public opinion both before and after the election showed a small majority in support of the proposal. Examining voting patterns showed a small net gain for the Liberals among those voters in both 2006 and 2008 who thought it was the most important election issue. In this case, however, environmentally-concerned voters were scattered across the electoral landscape, with the New Democratic Party (NDP) and the Greens also gaining from the issue. And responding to 
a question asking "which party would be best at protecting the environment?" the majority answer was the Green Party, indicating an overall hesitancy about the Liberals. The Liberals failed to forge a strong "link to party" on the issue. And once again, the discussion during the campaign largely bypassed the seriousness of the condition of the environment.

The carbon tax situation became an issue in the 2019 election in a different guise. The Liberals had not intended to impose a carbon tax at the federal level. Rather, they conceived of it as a "backstop" to be employed only in cases where provinces did not adopt plans consistent with federal requirements. As it turned out, several provinces refused to do so, including Ontario, New Brunswick, and the three western provinces of Saskatchewan, Manitoba, and Alberta. Therefore, a carbon tax was applied in these provinces, offset by federal rebates.

Recent Canadian public opinion polling has shown that carbon taxation is not necessarily the toxic policy position it is sometimes thought to be, a finding consistent with some of the election findings reported earlier. In 2012, a survey found that 51 percent favoured a carbon tax, with support highest in British Columbia and Quebéc (LaChappelle, Borick and Rabe 2012). Similar findings (49 percent support and 44 percent opposed) are reported from another study over the 2011-15 period (Mildenberger et al. 2016). An Angus Reid poll in October 2018 gave the national figures of 54 percent support and 46 percent opposed, although those figures were obtained only after the rebates were announced (Angus Reid 2018). In November 2018, Abacus Data reported that 59 percent of respondents agreed that "a national carbon price is a step in the right direction", and also that 57 percent said that "if [they] were an MP, [they] would vote for a carbon tax" (Anderson and Coletto 2018). In the event, the carbon tax was not a major issue in the 2019 election on its own, but emerged as a provincial rights issue in the Western provinces. Once again, the seriousness of the environmental/climate change situation was not centre stage in that discussion.

In Britain, one analysis states that "the issue salience of climate change rose sharply in the UK during 2019, with the result that the election took place in the context of record levels of concern about the environment" (Carter and Pearson 2020, 746). Nevertheless, the basis of issue choice between the major parties in the election was dominated by Brexit. Looking back to the 2016 referendum campaign on continued membership in the European Union, there was not much discussion about how Brexit might affect environmental protection efforts. The referendum produced a Leave majority and, subsequently, there has been considerable attention given to the implications of leaving the EU for continued cooperation on various issues including the environment (Hepburn and Teytelboym 2017; Farstad, Carter and Burns 2018). Arguments have gone both ways. The Conservatives have claimed that Brexit would give the UK an opportunity to fashion a climate change policy of its own, which could be a better one. In contrast, the Liberal Democrats have maintained that Brexit needs to be reversed so that a strong EU climate change policy would still be in force. Under the leadership of Jeremy Corbyn, Labour did not advocate a strong pro or con Brexit policy and was largely bypassed when environmental policy after Brexit was discussed. 
Figure 4. Top Three Most Important Issues in the 2015, 2017 and 2019 British General Elections

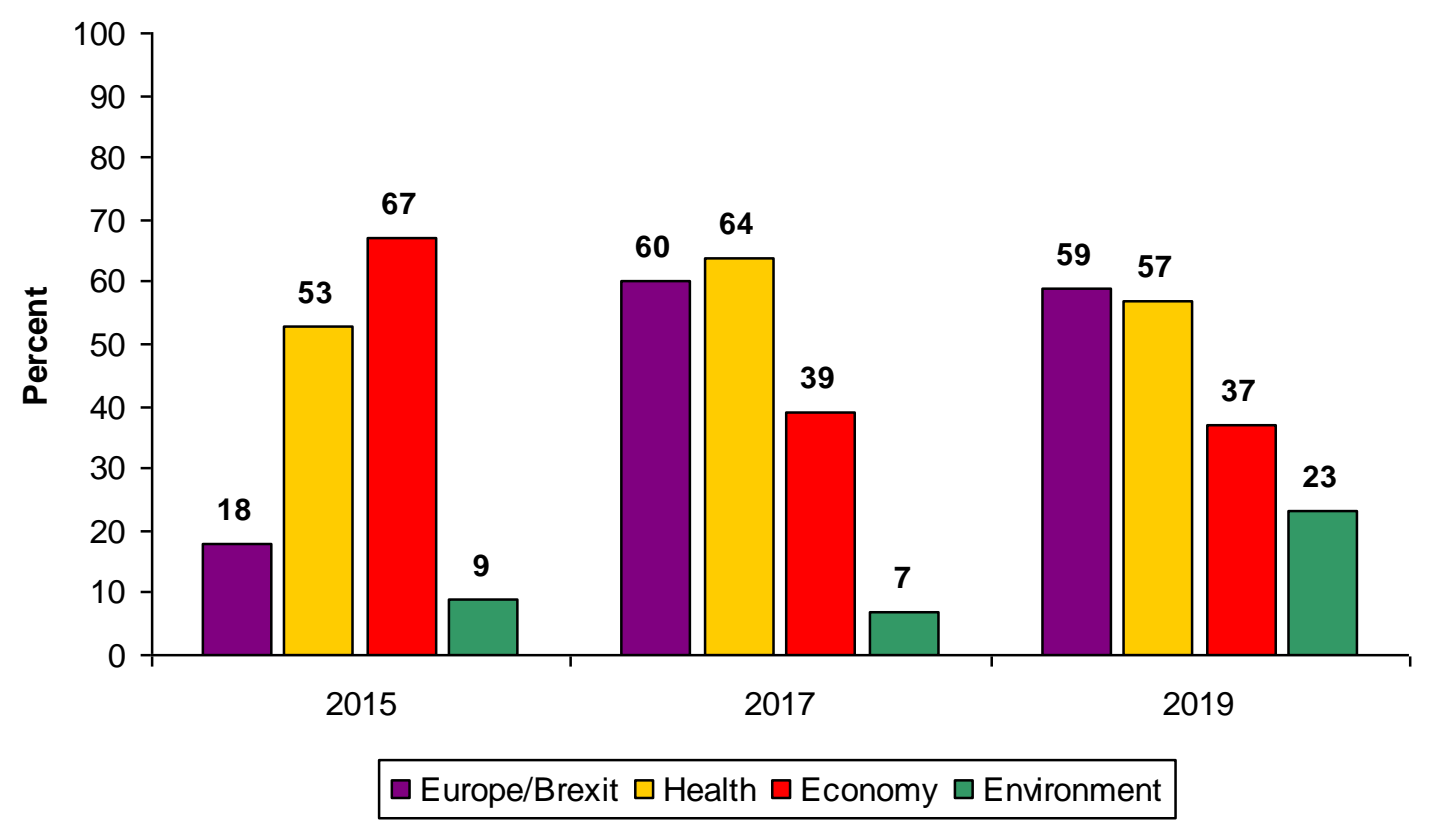

Source: 2015, 2017, 2019 UTD-Essex election surveys.

The British election issue agenda in 2019 was dominated by two topics: Brexit and the state of the National Health Service (NHS). When presented with a list of issues and asked to designate three as "most important", 59 percent of the respondents in the 2019 University of Texas at Dallas (UTD)-University of Essex national election survey chose Brexit, but nearly as many, 57 percent chose the NHS. ${ }^{45}$ As Figure 4 shows, the NHS also had been a very salient issue in the two preceding $(2015,2017)$ general elections, while relations with the European Union became a highly controversial topic in 2017 in the wake of the 2016 Brexit referendum and the acrimonious controversies and manifold uncertainties it precipitated. In contrast, the economy was persistently salient, although the percentage citing it declined from 67 percent in 2015 to 37 percent in 2019.

Historically, the environment has been a very minor issue in British general election campaigns and environmental concerns do little to explain the decisions voters make (Clarke et al. 2009). Parties and their leaders typically focus their campaigns on classic valence issues, emphasizing their ability to deliver economic prosperity, provide generous funding for the NHS, and protect the citizenry from threats to national and personal security. In this regard, Figure 4 shows that only seven percent of the 2015 UTD-Essex election survey respondents selected the environment

\footnotetext{
${ }^{5}$ Information about the 2015, 2017 and 2019 UTD-University of Essex Election Study data is available from the authors upon request. The data will be archived on the Harvard Dataverse (dataverse.harvard.edu) in the spring of 2021.
} 
as one of their top three issues. ${ }^{6}$ Nine percent did so in 2017 . However, similar to their Canadian counterparts, British voters responded differently in 2019, breaking the longstanding pattern of apparent disregard. Nearly one-quarter of them designated the environment as an important issue.

As will be discussed below, however, this heightened identification of the environment as an election issue had only minor effects on the choices Canadian and British voters made in 2019.

\section{Inadequate Election Manifestos}

Great Britain has a long history of party manifestos being published by political parties prior to every national election. These documents are expected, and indeed ostensibly sold, by all the major parties during the campaign. The 2019 election was no exception, but the three major parties differed substantially in the amount of attention they devoted to the environment. The Conservatives devoted only two of 64 pages to short statements of environmental promises in their document, Get Brexit Done (Conservative Party 2019). Emphasizing that "conservation is, and always has been, at the heart of Conservatism", the party promised to make investments in green technology, help industry to create new green jobs, and place a moratorium on fracking for oil $(2019,55)$. The Conservatives also promised to improve Britain's natural environment by tree planting and creating new national parks, and they made a point of saying "we will make no changes to the Hunting Act" $(2019,43)$, in reference to an issue which had divided the party due to the banning of the traditional practice of using dogs to hunt foxes and other animals.

Labour, in contrast, promised nothing less than "a green industrial revolution that will create one million jobs in the UK to transform our industry, energy, transport, agriculture and our buildings, while restoring nature", as the first item in its manifesto (Labour Party 2019, 12). The party also proposed creating several state institutions, like a Sustainable Investment Board, a National Investment Bank, a Local Transformation Fund, a UK National Energy Agency and 14 Regional Energy Agencies, and a complete new sustainable transport system (2019, 13-21). For their part, the Liberal Democrats' plan, Stop Brexit Build a Better Future, proposed "a ten-year emergency programme" to "insulate all Britain's homes by 2030", as well as to generate the majority of power from renewable sources (Liberal Democratic Party 2019, 41). A long list of government actions follows in the Liberal Democratic manifesto. The Liberal Democrats' pledge to stop Brexit meant they wanted to see EU environmental regulations retained, but the ambiguous Labour stand on Brexit meant it was unclear how their proposed environmental agenda would tie in with European climate change policies.

In 2019, the Canadian Liberal Party invited voters to Choose Forward: A Real Plan for the Middle Class, which promised to meet a number of climate change targets (Liberal Party of Canada 2019). The Liberals aimed to "achieve net-zero emissions by 2050 " by "set[ting] legallybinding, five year milestones, ... appoint[ing] a group of scientists, economists and experts, ... introducing new carbon-reducing measures, [and] giving workers access to the training, support

\footnotetext{
${ }^{6}$ Earlier British national election surveys employing an open-ended format for voters' issue concerns record even fewer mentions of the environment or related themes such as climate change or global warming (see, e.g. Clarke et al. 2009).
} 
and new opportunities needed to succeed in the clean economy" $(2019,29)$. These general statements are followed by pledges to plant two billion trees over 10 years, lower heating bills, and "help every Canadian child learn how to camp" (30-35). For the Conservative Party of Canada (CPC), Andrew Scheer's Plan for You to Get Ahead proposed to remove carbon taxes and replace them with "green technology", create "a cleaner and greener natural environment" and take "the climate change fight global" $(2029,38)$. Finally, Canada's NDP promised to "declare a climate emergency and put in place ambitious, science-based greenhouse gas reductions targets" which will "create over 300,000 good jobs in all communities" (2019, 43-44).

Some of these climate change plans were more ambitious than others; those of the Conservative parties in both countries were relatively minimal. Occasionally, the manifestos offered a choice; the Canadian Liberal Party proposed to "continue to lead with a price on pollution" $(2019,29)$ whereas the Conservatives would not use taxes to address climate change $(2019,39)$. None of the major party programs in either country addressed a potential environment-economy tradeoff, whereby job losses might occur in traditional energy industries. The closest any of them came to this was the reference in the manifesto of the British Labour Party to "transition" as part of the Green Industrial Revolution and to a Climate Apprenticeship program (Labour Party 2019, 18) to help with training in the green economy. Usually, however, the goals were lofty, the language determined, and the proposals to create government agencies, boards, commissions, and consultations, together with new green jobs, numerous. Nowhere were public sacrifices demanded, vital public policy choices outlined, or diminished futures predicted. Future targets were often a long way away, as with the Liberal Party of Canada's pledge to "achieve net-zero emissions by 2050" (2019, 29). Life in an environmentally-sustainable future would go along much as usual, except things would be better. The air would be cleaner, there would be fewer temperature extremes, and there would be lots of new "green" jobs.

Environmental concerns were presented as valence issues in all the party programs in both countries. Environmental protection was totally "upside" - there were no short- or long-term costs or tradeoffs involved. The only party to touch on a controversial policy was the reference by the Conservative Party of Canada to their determination to do away with a carbon tax. This position was not news to Canadian voters, as the Conservative party had opposed a carbon tax policy for many years, and had refused to countenance the idea when Stephen Harper was in power. The overall environmental component of the manifestos of both the Canadian and British Conservative parties was generally considered to be weak, and was a recognition that voters of both parties would be making decisions based on other issues, as will be shown in the next section. All the Canadian parties, however, tried to show their leaders in environmentally friendly situations, with pictures of Conservative Leader Andrew Scheer walking in the forest, and the Liberals' Justin Trudeau and the NDP's Jagmeet Singh both paddling canoes!

\section{The Environment and Voting in 2019}

As discussed above, valence issues typically dominate national election agendas in Canada, Britain, and elsewhere. Following the lead of seminal research by Stokes (1963; 1992), studies of voting behaviour in the two countries have documented that judgments about party performance on key valence issues such as the economy and healthcare typically have important effects on the 
choices voters make (e.g. Clarke et al. 2009; Clarke, Kornberg and Scotto 2009; see also Anderson 2010). The environment is a valence issue - overwhelming majorities of people prefer safe, sustainable environmental conditions and, accordingly, political debate focuses not on what the goal should be but rather "how to get there" and, especially, "who is best able to do it". Implicitly recognizing that they lack the omniscience long assumed by neo-classical economic theorists, voters acting in a world of high stakes and abundant uncertainty downplay the details of policy controversies and rely heavily on two key heuristics (cues) when making up their minds. ${ }^{7}$ One heuristic is partisanship; research shows that sizable numbers of Canadian and British voters have flexible party identifications which they are willing to update in light of recent party performance (Clarke and McCutcheon 2009; Clarke, Jenson, LeDuc and Pammett 2019). Party leader images are a second influential heuristic. Information about party leaders is in plentiful supply - leaders dominate the political stage during election campaigns and are the focus of intense, ongoing media attention in periods between elections. Voters use this information to form impressions of leaders' competence and responsiveness to public needs and demands. In turn, these leader images provide important cues that do much to guide voters' ballot choices. The indirect effects of issues will be considered shortly.

The valence politics theory of electoral choice informs our analysis of the impact of environmental concerns on voting in Canada and Britain in 2019. We specify a multivariate model using partisan identifications, party leader images, and judgments about classic valence issues (the economy, health services) as central predictor variables. ${ }^{8}$ To assess the impact of environmental concerns, we focus on judgments about whether job creation should be given priority over protecting the environment. Other predictors include attitudes towards Brexit (in Great Britain), immigration and general left-right ideological orientations. Several sociodemographics (age, educational attainment, gender, income, region of residence) are also included. Since the dependent variables are dichotomies (e.g., vote Liberal $=1$, vote another party $=0$ ), we use binomial logit procedures to estimate model parameters (e.g., Long and Freese 2014). We employ data from the 2019 CES for the Canadian analysis and data from the 2019 UTD-Essex Election Survey in the British analysis.

\footnotetext{
${ }^{7}$ On the importance of heuristics in human decision-making more generally see, e.g., Gigerenzer (2008).

${ }^{8}$ Details about the construction of variables used in the Canadian and British voting models are available from the authors upon request.
} 
Figure 5: Most Important Predictors of Voting in the 2019 Canadian Federal Election

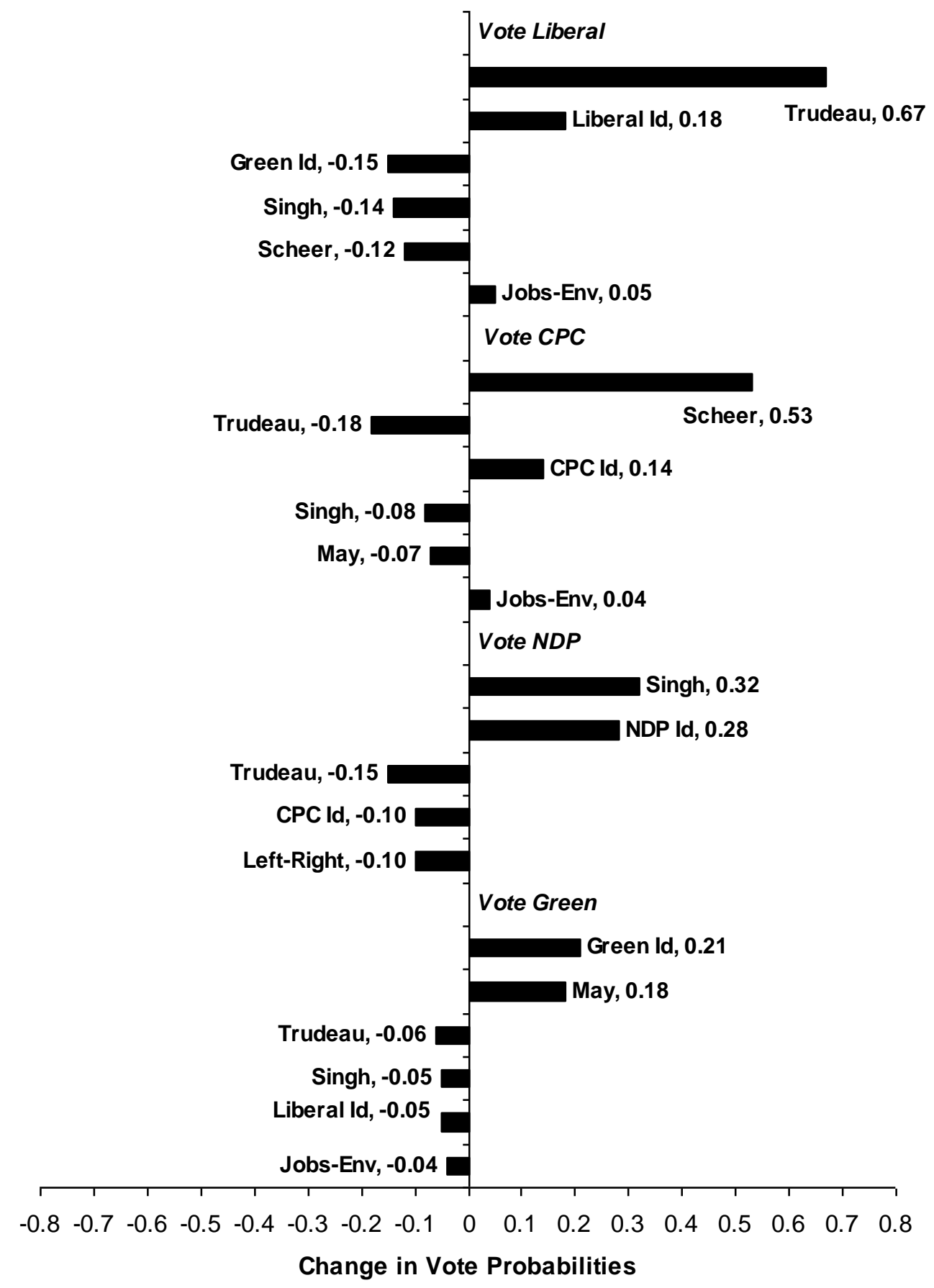

Note: probabilities calculated from binomial logit analyses of factors affecting voting for various parties. 
Figure 5 displays key results of this modeling exercise for voting in the 2019 Canadian federal election. ${ }^{9}$ This figure shows the ability of the most influential, statistically significant predictors to change the probability of voting for various parties. Considering Liberal Party voting first, and focusing on the five strongest predictors, we see that feelings about party leader Justin Trudeau are very important. As voters' feelings about him increase from highly negative to highly positive, the probability of voting Liberal increases by .67 points (on a $0-1$ scale). Feelings about the leaders of the Conservative and New Democratic parties are also influential factors in Liberal voting, but these effects are considerably weaker. Specifically, as feelings about Conservative Leader Andrew Scheer move from negative to positive, the probability of voting Liberal declines by .12 points. The comparable decrease as feelings about NDP Leader Jagmeet Singh go from negative to positive is .14 points. As expected, the probability of voting Liberal is also influenced by being a Liberal or a Green party identifier - Liberal identifiers are .18 points more likely to vote Liberal and Green identifiers are .15 points less likely to do so. Judgments that job creation should have priority over the environment have statistically significant, but small, effects. All else being equal, voters favouring jobs over environment have a .05 points greater probability of voting Liberal.

These results for Liberal voting are echoed in the analyses of voting for other Canadian parties. Party leader images are consistently paramount. Specifically, the probability of voting Conservative increases by .53 points as feelings about CPC leader Andrew Scheer moves from negative to positive. The comparable increase for NDP voting as feelings about party leader Jagmeet Singh increase is .32 points and that for Green voting as feelings about party leader Elizabeth May increase is .18 points. Similar to the Liberal analysis, the list of the other top five predictors is dominated by partisanship variables. The only exception is left-right ideological orientations which, when moved across the scale from left to right, reduce the likelihood of NDP voting by .10 points. Again, the direct impact of favouring jobs over the environment is very modest, increasing the probability of a Conservative vote by .04 points and reducing the probability of a Green vote by an equal amount.

${ }^{9}$ Estimated parameters for the Canadian and British vote models are presented in Appendices A and B, respectively. 
Figure 6: How Beliefs About Whether Jobs Should Have Priority Over Environment Affected Feelings About Party Leaders in the 2019 Canadian Federal Election

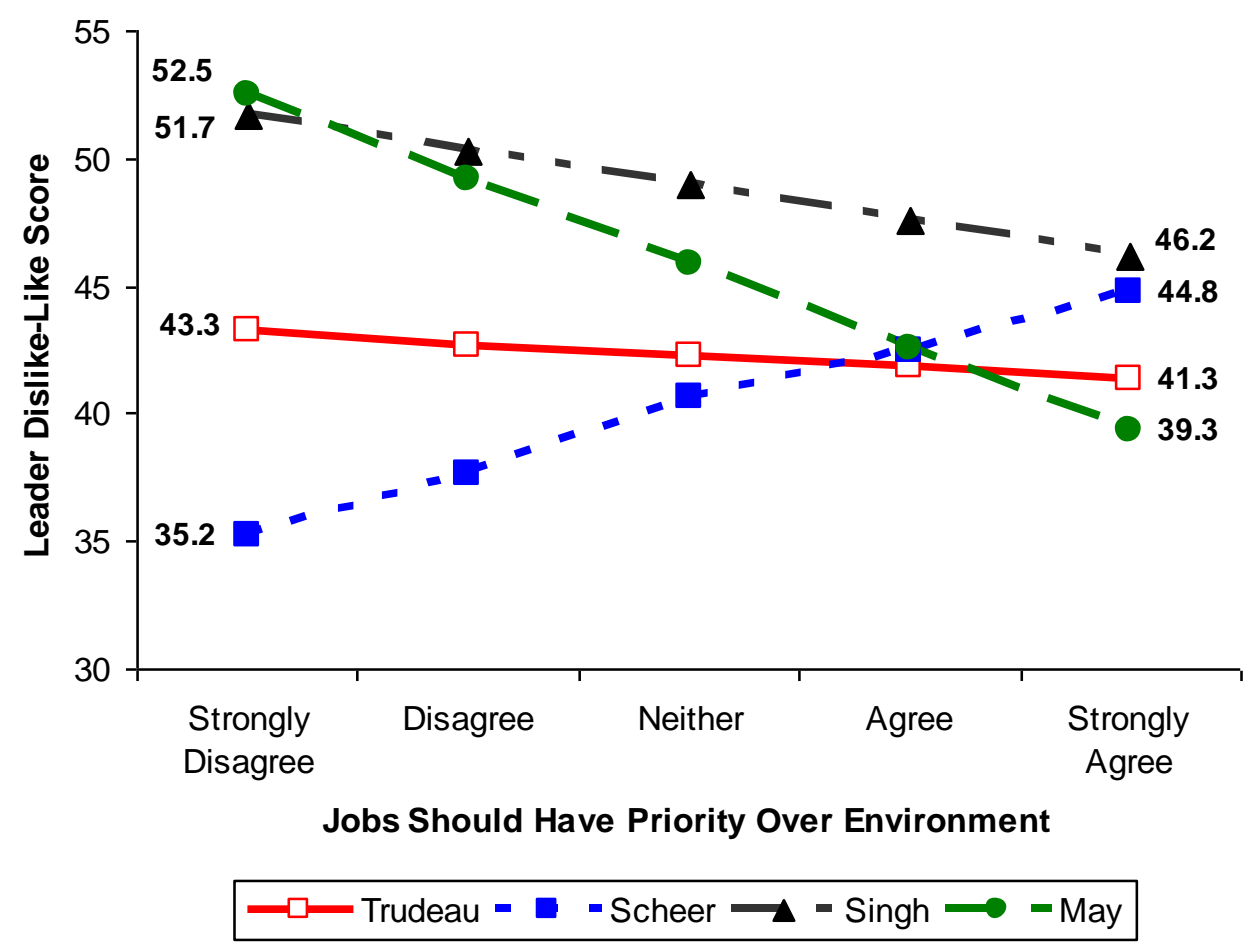

Note: feelings about Canadian party leaders measured on 0-100 dislike-like scale.

The dominance of leader images in these analyses suggests the possibility that environmental concerns exerted significant indirect effects on voting by working to shape feelings about the leaders. To assess this possibility, we performed a second set of multivariate analyses using these feelings (measured on a 0-100 dislike-like scale) as dependent variables. In addition to the "priority of jobs over environment" variable, predictors included all those used in the voting model described above. Figure 6 summarizes the model estimates of the impact of the jobs over environment variable on leader images. As shown, the largest effects are for Conservative leader Andrew Scheer, and Green leader Elizabeth May. In Scheer's case, average feelings about him are 35.2 among voters who "strongly disagree" that jobs should be given priority over the environment to 44.8 among those who "strongly agree" with this proposition. The effect on feelings about Elizabeth May are larger but, as expected, move in the opposite direction, decreasing from 52.5 among those favouring the environment to 39.3 among those prioritizing jobs. Effects for the NDP and Liberal leaders are considerably smaller. In both cases, these leaders are more warmly received by voters who favour the environment over jobs, with feelings about Jagmeet Singh moving from 51.7 to 46.2 and from 43.2 to 41.3 for Justin Trudeau. 
Overall, these results indicate that attitudes toward the environment mattered in the 2019 Canadian federal election, but the effects are largely indirect and modest in size. ${ }^{10}$

Figure 7: Most Important Predictors of Voting in the 2019 British General Election

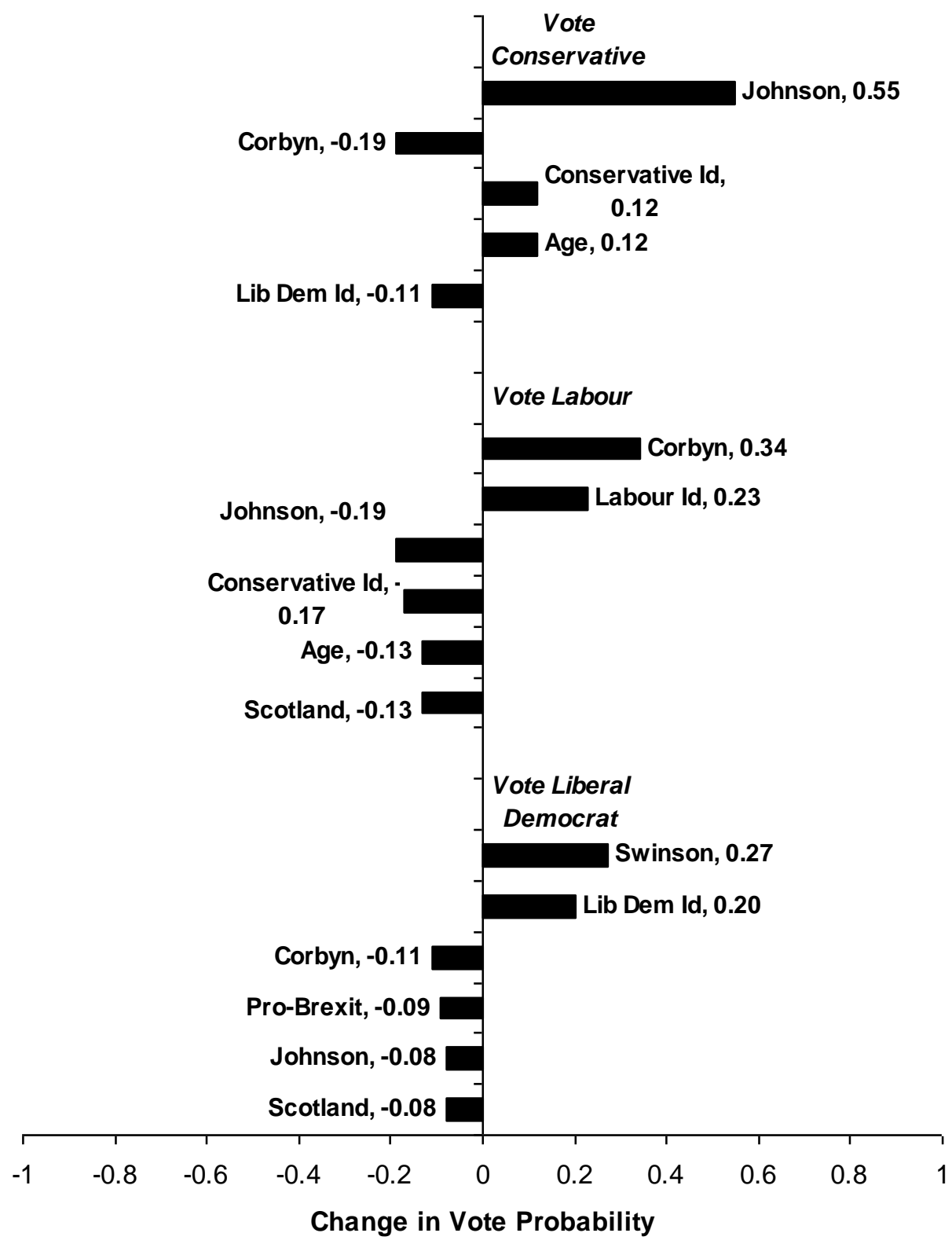

Note: probabilities calculated from results of binomial logit analyses of factors affecting voting for various parties.

10 This finding remains unchanged if mentions of the environment as most important issue are used in the multivariate analyses of voting and feelings about party leaders rather than priority accorded to the economy versus the environment. 
Results of similar multivariate models of factors affecting voting in the 2019 British general election are shown in Figure 7. Given the very small number of Green Party voters in the UTDEssex survey, we do not do a separate analysis of voters for that party. The major message of Figure 7 in the present context is the absence of direct effects of environmental concerns on Conservative, Labour, and Liberal Democrat voting. Neither designating the environment as a most important issue nor giving priority to the environment over the economy is a top-five predictor of voting for any of these parties. And, only in the Labour analysis, does one of these predictors (environment as a most important issue) have a significant effect, working to decrease the probability by .04 points.

Similar to the Canadian analyses, the major predictors of voting in the 2019 British election are leader images and partisanship. For example, very positive rather than very negative feelings about Conservative leader Boris Johnson increase the probability of a Conservative vote by .55 points. Comparable changes in feelings about Labour leader Jeremy Corbyn and Liberal Democrat leader Jo Swinson boost the likelihood of voting Labour or Liberal Democrat by .34 and .27 points, respectively. Figure 7 also shows that partisan attachments had several "top five" effects, although the strength of these effects was considerably less than the impact of leader images.

Figure 8: How Beliefs about Priority of Environment Versus Economy Affected Feelings About Party Leaders in 2019 British General Election

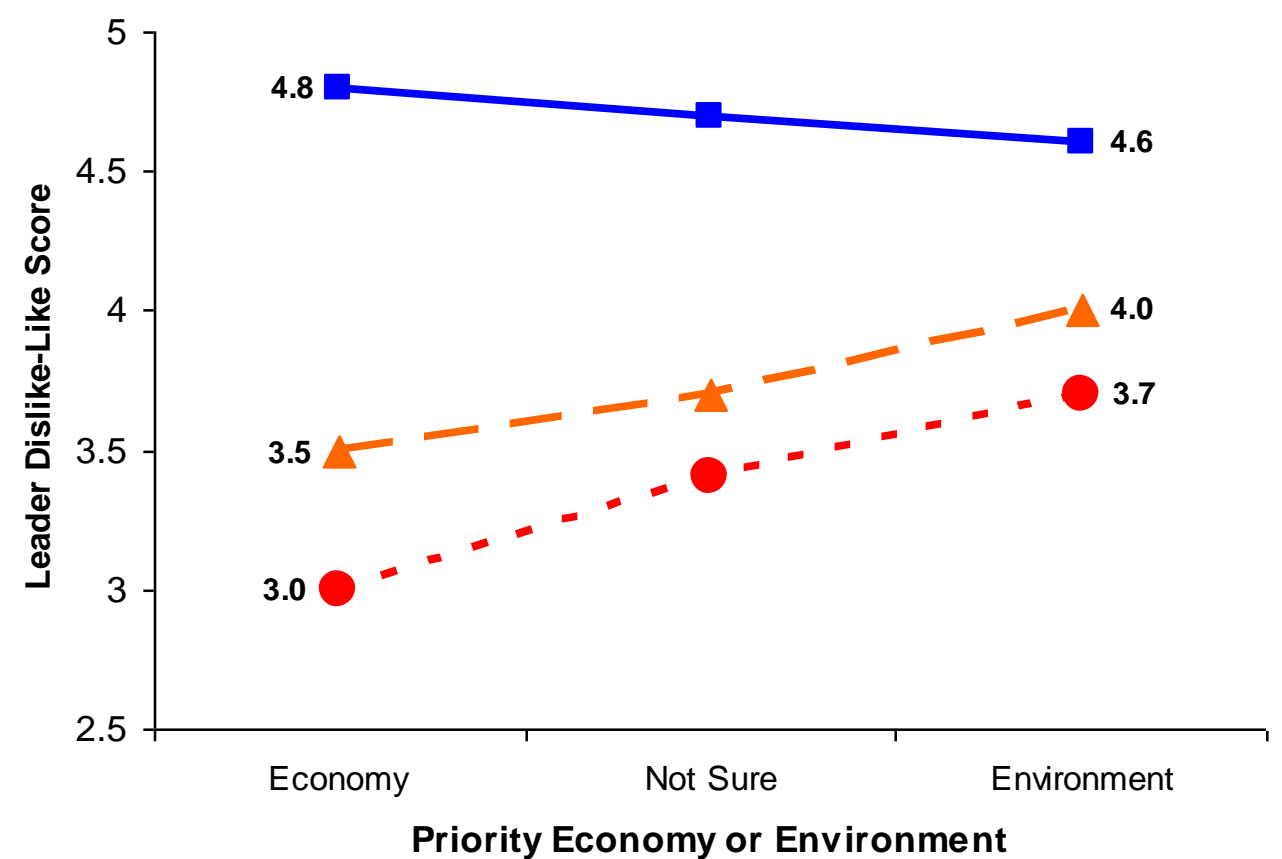

$\rightarrow$ Johnson $=-$ - Corbyn $\longrightarrow-$ Swinson

Note: feelings about British party leaders measured on 0-10 dislike-like scale. 
As in the Canadian case, we also investigate whether environmental concerns have indirect effects by influencing how British voters react to the party leaders. For this purpose, we employ multivariate models identical to the voting analyses just described. The results show that designating the environment as an important issue and giving priority to the environment over jobs have negative effects on feelings about Boris Johnson. In contrast, favouring the environment rather than jobs has positive effects on feelings about Jeremy Corbyn and Jo Swinson. As Figure 8 illustrates, average feelings about Johnson on a 0 (dislike) to 10 (like) scale only move from 4.8 among those favouring the economy to 4.6 among those emphasizing the environment. Effects on feelings about Corbyn and Swinson are somewhat larger. Average feelings about Corbyn increase from 3.0 among voters prioritizing the economy to 3.7 among those favouring the economy, with the comparable scores for Swinson being 3.5 and 4.0. These modest indirect effects of environmental concerns on electoral behaviour via leader images provide additional testimony of the failure of environmental issues to "cut through" in the 2019 British general election.

\section{Limited Impact on Election Outcomes}

Finally, we look at the limited possibilities for environmental/climate change issues to affect the overall results of the 2019 Canadian and British elections. To do this, survey respondents choosing environment as their most important issue (Canada) or as one of their three most important issues (Britain) have been identified in Tables 1 and 2, for comparison with respondents choosing other issues. To create this table, we identified the reported status and behaviour of the respondents in the previous election (2015 in Canada and 2017 in Britain) and cross-tabulated this with reported vote in 2019. By computing percentages over the entire complement of 2019 voters, we can measure the effect of the environment issue on the magnitude and direction of overall flows of the vote between the two most recent elections. 
Table 1: Effects of the Environment, Economy and Other Issues in the 2019 Canadian Federal Election

A. Environment

$\begin{array}{lccccc} & \text { Liberal } & \text { CPC } & \text { NDP } & \text { BQ } & \text { Green } \\ \text { Switch To } & 0.9 & 0.05 & 1.3 & 1.0 & 1.6 \\ \text { Remain With } & 5.0 & 0.8 & 1.4 & 0.8 & 0.7 \\ \text { Re)Enter } & 0.6 & 0.3 & 0.8 & 0.2 & 0.5 \\ \text { Total } & 6.6 & 1.6 & 3.5 & 2.0 & 2.8 \\ \text { B. Economy } & & & & & \\ & & & & & \\ \text { Switch To } & \text { Liberal } & \text { CPC } & \text { NDP } & \text { BQ } & \text { Green } \\ \text { Remain With } & 0.6 & 1.0 & 0.7 & 0.3 & 0.3 \\ \text { Re)Enter } & 3.6 & 4.8 & 0.7 & 0.1 & 0.1 \\ & 0.6 & 0.7 & 0.3 & -1- & 0.1 \\ \text { Total } & 4.8 & 6.5 & 1.7 & 0.4 & 0.4 \\ \text { C. All Other Issues } & & & & & \\ & & & & & \\ \text { Switch To } & \text { Liberal } & \text { CPC } & \text { NDP } & \text { BQ } & \text { Green } \\ \text { Remain With } & 2.2 & 4.2 & 3.8 & 2.2 & 1.2 \\ \text { Re)Enter } & 12.4 & 13.3 & 3.4 & 1.5 & 0.8 \\ \text { Total } & 2.2 & 2.3 & 1.9 & 0.4 & 0.8 \\ \text { N } & 14.6 & 19.8 & 9.1 & 4.1 & 2.8\end{array}$

Source: 2019 CES pre-election survey 
Table 2. Effects of Brexit, NHS, Economy and Environment in the 2019 British General Election

A. Brexit

$\begin{array}{lccccc} & & & \text { Liberal } & & \text { Other } \\ & \text { Conservative } & \text { Labour } & \text { Democrat } & \text { Green } & \text { Party } \\ \text { Switch To } & 6.2 & 3.1 & 3.6 & .7 & 3.4 \\ \text { Remain With } & 27.7 & 10.2 & 4.3 & .5 & 3.2 \\ \text { Re)Enter } & 2.0 & 1.1 & .5 & .7 & 1.3 \\ \text { Total } & 35.9 & 14.4 & 8.4 & 1.5 & 7.9\end{array}$

B. NHS, Health Care

$\begin{array}{lccccc} & & & \text { Liberal } & \text { Other } \\ & \text { Conservative } & \text { Labour } & \text { Democrat } & \text { Green } & \text { Party } \\ \text { Switch To } & 5.7 & 4.5 & 3.0 & .9 & 2.6 \\ \text { Remain With } & 17.9 & 14.2 & 4.5 & .3 & 3.0 \\ \text { Re)Enter } & 1.6 & 1.4 & .4 & .3 & .9 \\ \text { Total } & 25.2 & 20.1 & 7.9 & 1.5 & 6.5 \\ \text { C. Economy } & & & & & \end{array}$

$\begin{array}{lccccc} & & & \text { Liberal } & \text { Other } \\ & \text { Conservative } & \text { Labour } & \text { Democrat } & \text { Green } & \text { Party } \\ \text { Switch To } & 2.9 & .7 & 2.1 & .5 & 1.5 \\ \text { Remain With } & 10.0 & 7.6 & 2.7 & .6 & 1.8 \\ \text { Re)Enter } & 1.4 & 1.2 & .3 & .1 & .8 \\ \text { Total } & 14.3 & 9.5 & 5.1 & 1.2 & 4.1\end{array}$

D. Environment

Switch To

Remain With

Re) Enter

Total

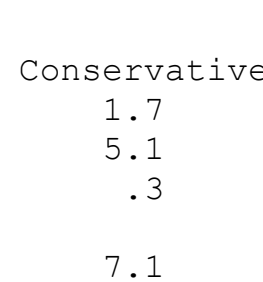

Liberal
Democrat
1. 4
2.4
.5
4.3

$\begin{array}{cc}\text { Green } & \text { Other } \\ .7 & \text { Party } \\ .1 & 1.1 \\ .2 & .9 \\ 1.0 & .4 \\ & 2.4\end{array}$

Source: 2019 UTD-Essex election survey

Panel 1 in Table 1 shows that there was a modest impact of environment on the outcome of the 2019 Canadian election, in the sense that all parties except the Conservatives benefitted. In particular, the largest number in this panel (five percent of 2019 voters) are 2015 Liberal voters who stayed with their party because of the environment issue. The largest amount of vote switching between the two elections was comprised of people moving to the Greens, but this is a relatively small number overall (1.6 percent of 2019 voters). The data in Table 1 thus emphasize that the environment was only one issue among many with quite modest effects on the 2019 Canadian federal election. The economy was almost as important to the Liberals, and considerably more important to Conservative voters. A wide variety of other issues was cited by 
people choosing the various parties. The limited impact, and the nebulous way the environment issue was defined in the party manifestos, means that the resulting Liberal Government had little explicit instruction from the public about the policies they should undertake, except, of course, that those policies should move "forward" and create "good jobs". Who would disagree?

In Britain, the pattern of issue choice was considerably different, but the impact of the environment (Table 2, panel D) was, if anything, less important than it was in Canada. (Bear in mind that three issue choices were allowed in the question in Britain, so all the totals are higher than those in Table 1 for Canada.) The overall effect of environmental issue voting did not favour any of the larger parties, and the impact was considerably lower than that for the economy (panel C), the healthcare system (panel B), and especially for Brexit (panel A), an issue vital to the Conservative victory in the election. Given the minimal specifics expressed in the victorious Conservative Party manifesto, and uncertainties about Brexit arrangements to be negotiated with the EU, the election did precious little to clarify the future course of British environmental policy.

\section{Conclusion: Not Easy Going Green}

The environment is primarily presented as a valence issue in Canadian and British elections. Defined as a large societal problem which all parties and their leaders promise to address if elected, it has competed with several other well established valence issues; this was certainly the case in the two electoral contests considered in detail here. The other two most important valence issues, the economy and healthcare, can be presented as complementary to environmental concerns, in that a "green" economy can create jobs, and a cleaner environment can alleviate demands on the health system. Often, however, there is competition among these three valence issues for salience, funding, and policy direction. Money spent on the environment can mean money not spent on hospitals and the health system. Strict environmental regulation and carbon taxes can be presented as costing jobs and emptying the public's wallets. This helps to explain why in times of economic recession, or in times of health emergencies, environmental issues can get pushed to the sidelines. A further illustration is provided by the fact that the 2020 coronavirus pandemic forcefully depressed public opinion identifying the environment as the most important problem facing the country to, in the Canadian case, less than half its January value in April and May (Nanos 2020). Our analysis of the party manifestos presented earlier shows that none of the parties contesting the 2019 Canadian and British elections presented environmental protection in terms which competed with other fields; rather, voters were invited to tacitly assume that the economy would be buoyed by green jobs and a cleaner environment would produce a healthier population.

When they are addressed by the parties, and all parties devote attention (sometimes considerable attention) to environmental issues in their manifestos, their words sound sincere and their proposed actions sound sensible. All the major parties are adept at creating virtue-signaling "environmental action plans" which do not demand sacrifices on the part of voters, such as the plans to plant large numbers of trees proposed by several parties in both countries in 2019 . When dealing with the subject of jobs, parties try to avoid colliding with environmental concerns by proposing to create "new green jobs" rather than focusing on job losses in fossil fuel industries. Carbon taxes are not stressed, but when parties are brave enough to admit to plans to impose 
them, these taxes are offset with rebates or with subsidies to promote purchasing electric vehicles. Electricity pricing not being a responsibility of national governments, any additional costs there may be ignored.

The result, as we have shown here, is that environmental issues, despite being identified as major problems, have not been major factors influencing voting behaviour or election outcomes in Canada or Britain, despite the amount of virtuous rhetoric expended on them during campaigns. Where environmental issues do influence votes, there is seldom a link to a party that is robust enough to strongly favour one of them, and we have seen that many voters citing the environment as their most important issue use this as a rationale for staying with the party they supported in the previous election. Overall flows of votes based on environmental issues from one party to another are not large enough to determine the outcomes of elections, certainly not the two elections examined here.

Can we envision future British or Canadian elections where environmental issues, whether defined as climate change or in some other form, have a major impact on voting and results? It is tempting to argue that this would happen only if three conditions are met. First, a large segment of the public must be convinced that that there is, in fact, an environmental crisis that requires immediate action, a crisis so severe that it supercedes other more immediate events and conditions. Second, there must be a clear differentiation among the political parties as to the actions they wish to take. Third, electorates must be willing to undergo the dislocations and sacrifices, financial and otherwise, that may be necessary for effective action to address the issue. We may be waiting some time yet for these circumstances to occur. "Kicking the can down the road" can be a very tempting strategy for power-seeking parties and their leaders. 


\section{REFERENCES}

Anderson, Bruce and David Coletto. 2018. "Can the Conservatives win in 2019 by running against carbon pricing?" Abacus Data, November 4, 2018. https://abacusdata.ca/can-theconservatives-win-in-2019-by-running-against-carbon-pricing-its-no-slam-dunk/ . 2019. "Will climate change be a ballot box question in 2019?" Abacus Data, March 27, 2019. https://abacusdata.ca/will-climate-change-be-a-ballot-box-question-in-2019/

Anderson, Cameron. 2010. "Economic Voting in Canada: Assessing the Impact of Subjective Conditions and Electoral Context." In Voting Behaviour in Canada, edited by Cameron Anderson and Laura Stephenson. Vancouver: University of British Columbia Press.

Angus Reid. 2018. "Carbon Pricing: Rebate announcement tips opinion in favour of federal plan, slim majority now support it." October 31, 2018. http://angusreid.org/wpcontent/uploads/2018/10/2018.10.31_ClimateChangeFinal.pdf

Carter, Neil, and Mitya Pearson. 2020. “'A Climate Election': The Environment and the Greens in the 2019 UK General election.” Environmental Politics 29 (4): 746-751.

Clarke, Harold D., David Sanders, Marianne C. Stewart and Paul Whiteley. 2009. Performance Politics and the British Voter. Cambridge: Cambridge University Press.

Clarke, Harold D., Jane Jenson, Lawrence Leduc and Jon H. Pammett. 1984. Absent Mandate: The Politics of Discontent in Canada. Toronto: Gage. . 2019. Absent Mandate: Strategies and Choices in Canadian Electoral Politics. Toronto: University of Toronto Press.

Clarke, Harold D., Allan Kornberg and Thomas J. Scotto. 2009. Making Political Choices: Canada and the United States. Toronto: University of Toronto Press.

Clarke, Harold D. and Allan McCutcheon. 2009. "The Dynamics of Party Identification Reconsidered." Public Opinion Quarterly 73 (4): 704-728.

Conservative and Unionist Party. 2019. Get Brexit Done: Unleash Britain's Potential. London.

Conservative Party of Canada. 2019. Andrew Scheer's Plan for You to Get Ahead. No location stated.

Duverger, Maurice. 1954. Political Parties - Their Organization and Activity in the Modern State. London: Methuen.

Everts, Sarah and Susan Harada. 2020. "The Climate Referendum: The Greens, the Others, and the Politics of Climate Change." In The Canadian Federal Election of 2019, edited by Jon H. Pammett and Christopher Dornan. Montreal: McGill-Queen's Press.

Farstad, Fay, Neil Carter and Charlotte Burns. 2018. "What Does Brexit Mean for the UK's Climate Change Act?" The Political Quarterly 89 (2): 291-297. 
Gigerenzer, Gerd. 2008. Rationality for Morals: How People Cope With Uncertainty. Oxford: Oxford University Press.

Hepburn, Cameron and Alexander Teytelboym. 2017. "Climate Change Policy After Brexit." Oxford Review of Economic Policy 33 (1): S144-S154.

IPSOS. 2019. What Worries the World? September, 2019. https://www.ipsos.com/sites/default/files/ct/news/documents/2019-11/what-worries-theworld-september-2019.pdf

Labour Party. 2019. A Time for Real Change: The Labour Party Manifesto 2019. London.

Liberal Democratic Party. 2019. Stop Brexit: Build a Better Future. London.

Liberal Party of Canada. 2019. Choose Forward: A Real Plan for the Middle Class. No location stated.

Lachapelle, Erick, Christopher P. Broick and Barry Rabe. 2012. "Public Attitudes toward Climate Science and Climate Policy in Federal Systems: Canada and the United States Compared." Review of Policy Research 29 (3): 334-357.

LeDuc, Lawrence and Jon H. Pammett. 2016. Dynasties and Interludes: Past and Present in Canadian Electoral Politics, $2^{\text {nd }}$ edition. Toronto: Dundurn.

Long, J. Scott and Jeremy Freese. 2014. Regression Models for Categorical Dependent Variables Using Stata, $3^{\text {rd }}$ edition. College Station: Stata Press.

Mayer, Adam and E. Keith Smith. 2017. "Rethinking Economic Conditions and Environmental Attitudes: Macroeconomic Effects, Individual experiences, and Subjectivity." Social Currents 4 (4) no pages available.

Mildenberger, Matto, Peter Howe, Erick Lachapelle, Leah Stokes, Jennifer Marlon and Timothy Gravelle. 2016. "The Distribution of Climate Change Public Opinion in Canada." PLOS|ONE 11 (8): e0159774.

Nanos. 2020. Nanos Weekly Issue Tracking, week ending May 29, 2020, www.nanos.co.

New Democratic Party of Canada. 2019. A New Deal for People: New Democrats' Commitments to You. No location stated.

Pammett, Jon H. and Christopher Dornan. 2009. The Canadian Federal Election of 2008 Toronto: Dundurn.

Pearson, Mitya, and Wolfgang Rudig. 2020. "The Greens in the European Elections." Environmental Politics 19 (2): 336-343.

Poushter, Jacob and Christine Huang. 2019. "Climate change Still Seen as the Top Global Threat, but Cyberattacks a Rising Concern.” Pew Research Center, February, 2019. 
Stokes, Donald E. 1963. "Spatial Models of Party Competition." American Political Science Review 57: 368-77.

. 1992. "Valence Politics." In Electoral Politics, edited by Dennis Kavanagh. Oxford: Clarendon Press. 


\section{Appendix A}

\section{Binomial Logit Models of Voting in the 2019 Canadian Federal Election}

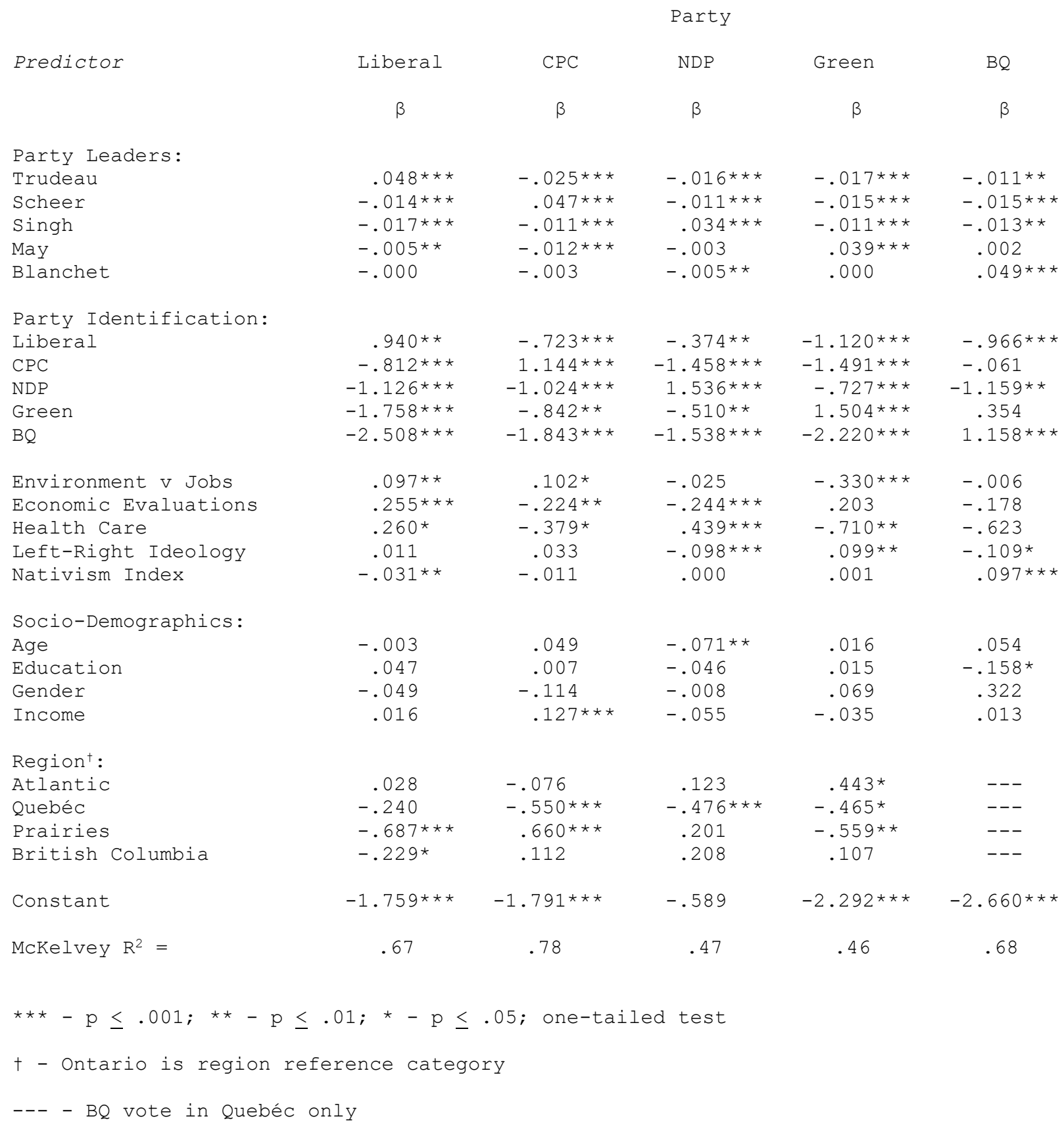




\section{Appendix B}

Binomial Logit Models of Voting in the 2019 British General Election

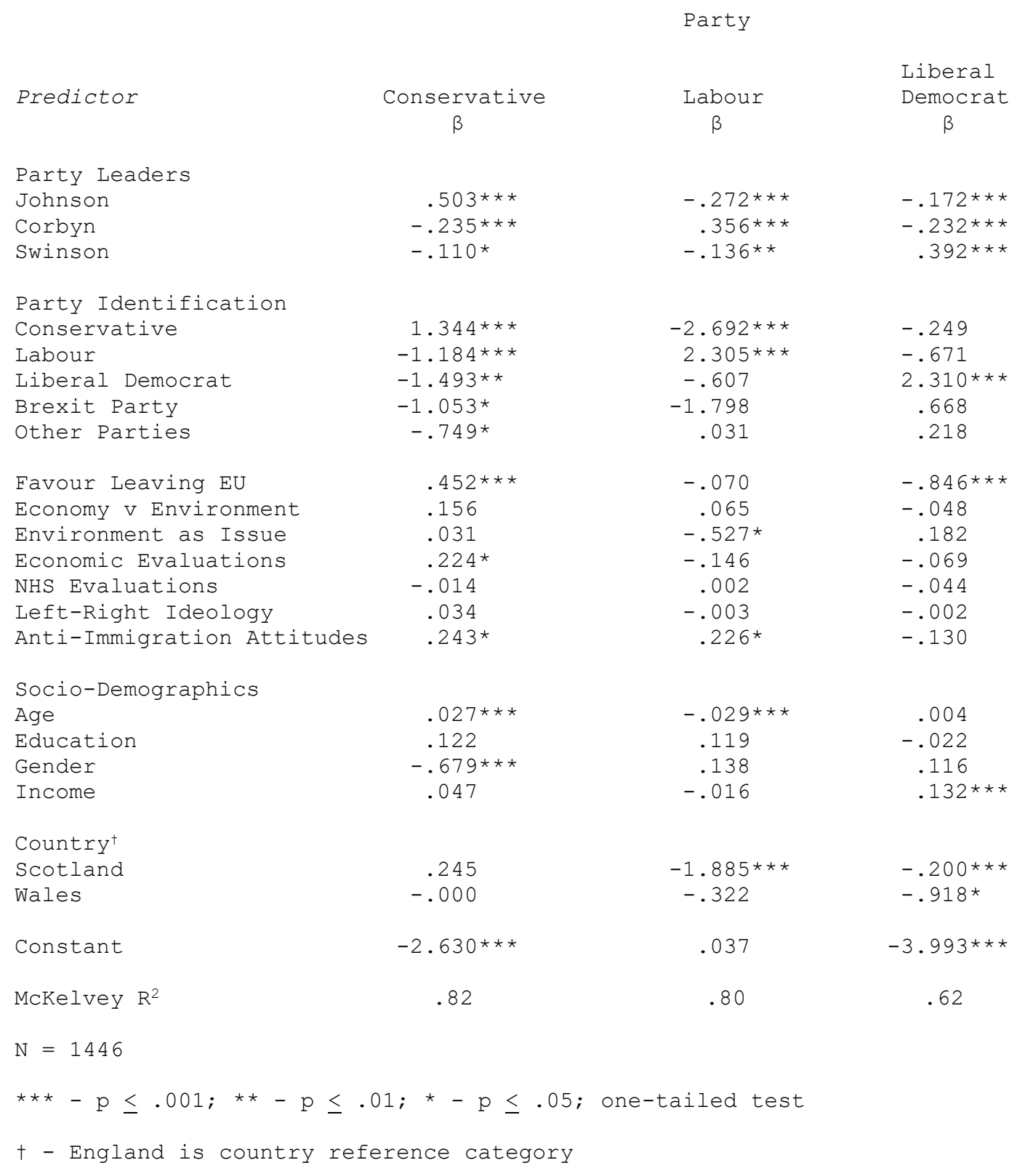


Published by the Centre for European Studies at Carleton University, Ottawa, Canada

Available online at: https://ojs.library.carleton.ca/index.php/CJERS/index

The Canadian Journal of European and Russian Studies (CJERS - formerly Review of European and Russian Affairs) is an open-access electronic academic peer-reviewed journal: articles are subject to double-blind peer-review. Topics relate to the European Union, its Member States, the former Soviet Union, and Central and Eastern Europe. The journal is published by the Centre for European Studies, an associated unit of the Institute of European, Russian and Eurasian Studies at Carleton University.

CJERS aims to provide an accessible forum for the promotion and dissemination of high quality research and scholarship.

\section{Contact:}

Carleton University

The Centre for European Studies

1103 Dunton Tower

1125 Colonel By Drive

Ottawa, ON K1S 5B6

Canada

Tel: +01 613 520-2600 ext. 3117; E-mail: CJERS@ @arleton.ca

\section{Creative Commons License}

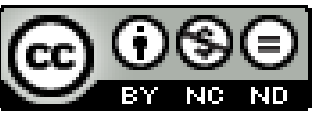

https://creativecommons.org/licenses/by-nc-nd/4.0/

This Working Paper is licensed under a Creative Commons Attribution-Non-CommercialNo Derivs 4.0 Unported License (CC BY-NC-ND 4.0).

Articles appearing in this publication may be freely quoted and reproduced, provided the source is acknowledged. No use of this publication may be made for resale or other commercial purposes.

ISSN: 2562-8429

(C) 2019 The Author(s) 